\title{
IMPACT OF THE RADIO POLITICAL PROGRAMMES ON PUBLIC POLITICAL AWARENESS IN JIGAWA STATE, NIGERIA
}

\author{
ALI ABDU GIGINYU ${ }^{1}$, HAMIDU MOHAMMED JADA ${ }^{2}$, MUHAMMAD ALI MUTAH $^{3}$ \\ ${ }^{1}$ Federal University Dutse, Jigawa State, Nigeria, 08069337226, \\ aliabdullahigiginyu@yahoo.com \\ ${ }^{2}$ Federal University Dutse, Jigawa State, Nigeria, 07038417827, hamid.jada@ gmail.com \\ ${ }^{3}$ Federal University Dutse, Jigawa State, Nigeria, 080-3646-7811, 9256.mmali@ gmail.com
}

Correspondence Address: 08069337226, aliabdullahigiginyu@yahoo.com

\begin{abstract}
The research was conducted to assess the impact of the Radio Political Programmes on Public Political Awareness in Jigawa State, Nigeria. The specific objectives was to evaluate political awareness gained by the listeners of the Radio Political Programmes, ascertain the level of audience motivation for listening to the RPP, and determine the level of influence of RPP on audience Political decisions in Jigawa State, Nigeria. The data were analyzed with descriptive statistics i.e. frequency distribution and percentages. The population of the study includes the population of Jigawa state numbered 5,368,612, the sample size of the study were determined using Research advisor (2006) sample size table. Therefore, 384 were used as a sample size of the study. Simple Random Cluster Sampling was used for this study. 48 respondents were drowned from each eight (8) LGA as sample sizes of the study. The findings of the study shows that 70\% of the respondents listened to the Radio Political Programmes aired in Jigawa State admitted that were very strongly effective on the listeners Public Political Awareness in Jigawa State, it should therefore be sustained but with some recommendations in terms of, improve transmission, upgrade balance of information, improve radio teaching and learning process and community to involve in sponsoring radio programmes. The research it could serve as a document and a guide to policy makers' formulation radio political programmes, vital information for "Kowane Gauta" "Baki Kan Yanka Wuya" and "Kowa Ya Dakko Da Zafi" Radio political programmes in Jigawa State, Nigeria.
\end{abstract}

KEY WORDS: Public, Radio, Political, Programmes and Awareness 


\section{INTRODUCTION}

No one can doubt that mass media have a very important place in contemporary society, radio and television played important roles in building a worldwide peace after Second World War, it is referred to as "watch dog", because information is pivotal in our lives, we need information to do a lot of activities such as to resolve problems, to make a decision, to reduce the uncertainty, to resolve conflict, to answer questions and to satisfy curiosity, improve our productivity as well as in our political awareness. Radio and television today are important channels in the communication and broadcasting sector, radio is democratic in nature it reaches a large number of people, radio is portable, people can listen to radio anytime, anywhere, it does not need expensive and large infrastructures like other medias, it remains the most used mass-communication medium, it has widest geographical and greatest audiences compared with the internet, television and newspapers, it doesn't run out of air time or data, it is free always and forever, it reaches rich and poor, educated, uneducated, young, old, every tribe, every region, each gender and race, radio informs and educates, it's the most effective way of delivering information, radio programmes are broadcast in local languages-whether it's nutrition information for mother, economic aspect, political awareness, social aspect, religious awareness, medical update for health workers, conservation farming for farmers, harvesting, hunger eradication or school lesson for children and therefore it can be accessed and used by almost everyone, this convenience makes radio the most extensive and widely used tool among other mass communication tools, radio still plays a vital role into day's world, radio is more than just announcers, news and songs, radio is about companionship and the emotional connection with the listener. radio broadcasts provide real-time information, and some that broadcast 24 hours a day, can provide the most recent updates to listeners, radio has the ability to reach across borders and can become a valuable source of information where reliable news is scarce, radio has proved its worth in times of emergency such as when access to the mobile net work is down as a result of an overload, or phone lines are cut. For many decades, radio is life-saving; broadcasters have been the primary source of critical information to the public in the event of disasters such as tornadoes, hurricanes, floods, snowstorms, earthquakes, tsunamis, corona virus (COVID-19) pandemic and even terrorist attacks and industrial catastrophes, due to their wide coverage (Sanjay, 2013).In recognition of the unique nature of radio in terms of simplicity, wider coverage bringing the world to those who cannot read, its immediacy (Micleish, 1978), Kupuniyi, (2000) stated that: Radio is one broadcast medium which almost all experts identify to be the most appropriate for rural emancipation programme. It beats distances, and thus has immediate effect. It has been identified as the only medium of mass communication the rural population is very familiar with. Even when there is no electricity, most radio sets can be battery operated or has the ability to be hand-cranked. Radio is not just important for reception of emergency announcement sand communications during disasters; it provides an outlet for regular community messaging and activities such as local sports, community events, special events, local business advertising, etc. More importantly, radio is easy to use, it's live and it's human, radio has survived and prospered by being the easiest of media to use, wake up in the morning, have a shower, get in the car, and turn on the radio, Propaganda is another function of the radio that can be considered within the scope the news function. Radio is one of the most important inventions that effected and changed the social life substantially, radio drew the attention of large masses in a short time, (Bay, 2007). Radio is favoured as a medium of communication in rural communities because of the advantages ascribed to it in form of transcending the barriers of illiteracy and demanding less intellectual exertion than the print media messages (Folarin, 1990). In general, functions of the radio are 
classified in five groups as: news information, education, advertisement, entertainment and persuasion and actuation (Ozturk, 2003). Radio like any other mass medium is used to educate, entertain, inform and socialize the people (Mcquil, 1998). It helps in providing individual reward, relaxation and reducing of tension, which makes it easier for people to cope with real life problems nd for societies to avoid breakdown (Mendelson, 1966). Propaganda described as imposing an idea, attitude and behaviour to an individual, group or the entire society by using certain techniques and methods. It is something between news and education functions. Media, an important actor of the political communication, is used frequently by political powers for spreading and multiplying the effect of political messages particularly the radio has been used frequently. Radio maintained its dominance in propaganda until the start of television broadcasting (Mihalis, 2006). Radio is considered as an effective tool to disseminate political awareness/information among the community and it is one of the most powerful mass media for broadcasting Information quickly. It is a powerful communication medium, particularly in Nigeria people have to depend on radio to meet their needs for information. Radio can reach large audience at the same time. In terms of cost, it is an extremely economical medium as compared to other extension media and methods involving individual and group contacts. Radio is considered as a credible source of information and is taken as authentic, trustworthy and prestigious medium of communication" (Kakade, 2013). As well as its contribution to the development of a nation, it is still the most credible source of news and enlightenment in most part of Africa (Okigbo, 1990), its transmission in various languages (Moemeka, 1981). In Nigeria, various communication media are being used to transmit political awareness/information to people in line with National Fundamental Human Rights policy on Freedom of expression, everyone has the right to freedom of expression. The communication media include farm magazine, leaflets, newsletters, newspapers, pamphlets, radio and television, among others (Dare, 1990). Among them, radio is the most preferred tool of mass communication in Nigeria (Zaria and Omenesa, 1992; Omenesa, 1997; Ekumankama, 2000). Nwuzor (2000) observed that radio programmes are usually timely and capable of extending messages to the audience no matter where they may be as long as they have a receiver with adequate supply of power. The absence of such facilities as road, light and water are no hindrance to radio. Similarly, such obstacles as difficult topography, distance, time and socio-political exigencies do not hinder the performance of radio. He further observed, that illiteracy is no barrier to radio messages since such messages can be passed in the audience own language. Another advantage of radio programme is that it can be done almost anywhere through the use of a tape recorder. It is probably because of these advantages of radio that many governments accord high priority to it as a means of reaching people. Among other sources of information, radio and TV also depicted value for information dissemination (Okwu and Daudu, 2011).

Every Nigerian has rights, duties, liabilities and privileges which are provided for in the hundreds of laws that exist in Nigeria. However, there are certain rights that are basically trump all other ones. They are rights that are referred to as in alienable rights, rights for which the law has made specific and special provision. These rights are contains in chapter IV of the 1999 constitution of the Federal Republic of Nigeria and are officially known as Fundamental Human Rights as follows:1.Right to life 2. Right to Dignity 3. Right to Personal Liberty 4. Right to Fair Hearing 5. Right to Privacy 6. Right to Freedom of thought conscience and religion 7. Right to freedom of expression 8. Right to freedom of assembly and association 9. Right to freedom of movements 10. Right to freedom of discrimination 11 Right to own property (FRNC, 1999). HRA, (2020) Article 10 of the Human Rights Act: Freedom of expression, everyone has the right to freedom of expression. This right shall 
include freedom to hold opinions and to receive and impart information and ideas without interference by public authority and regardless of frontiers. Article 10 protects your right to tell your own opinions and to express them freely without government interference. This includes the right to express your view aloud (for example through public protest and demonstrations) or through: published articles, books or leaflets television or radio broadcasting works of art, the internet and social media. The law also protest your freedom to receive information from other people by, for example, being part of an audience or reading a magazine, Although you have freedom of expression, you also have a duty to behave responsibly and to respect other people's rights public authorities may restrict this right if they can show that their action is lawful, necessary and proportionate in order to: protect national security, territorial integrity (the borders of the state) or public safety prevent disorder or crime, protect health or morals protect the rights and reputations of other people, prevent the disclosure of information received in confidence maintain the authority and impartiality of judges. An authority may be allowed to restrict your freedom of expression if, for example, you express views that encourage racial or religious hatred. However, the relevant public authority must show that the restriction is proportionate; in other words that it is appropriate and no more than necessary to address the issue concerned using this right example, this right is particularly important for journalists and other people working in the media. They must be free to criticize the government and our public institutions without fear of prosecution. This is a vital feature of a democratic society. But that doesn't prevent the state from imposing restrictions on the media in order to protect other human rights, such as a person's right to respect for their private life (Amnesty International, 2020). Freedom of speech is the right to seek, receive and impart information and ideas of all kinds, by any means. Freedom of speech and the right to freedom of expression applies to ideas of all kinds including those that may be deeply offensive. But it comes with responsibilities and we believe it can be legitimately restricted. Freedom of speech can be restricted, governments have an obligation to prohibit have speech and incitement. And restrictions can also be justified if they protect interest or the rights and reputations of other. Any restrictions on freedom of speech and freedom of expression must be sent out in laws that must in turn be clear and concise to everyone can and understand them. People imposing the restrictions (whether they are government's employers or anyone else) must be able to demonstrate the need for them, and they must be proportionate. All of this has to be backed up by safeguards to stop the abuse of these restrictions and incorporate a proper appeals process. Restrictions that do not comply with all these conditions violate freedom of expression. We consider people put in prison or solely for exercising their right to free speech to be prisoners of conscience. Any restriction should be as specific as possible, it would be wrong to ban an entire website because of a problem with one page. National security and public order these term must be precisely defined in a law to prevent them being used as excuses for excessive restrictions. Moral: this is a very subjective area, but any restrictions must not be based on a single tradition or religion and must not discriminate against anyone living in a particular country. Right and reputations of others public officials should tolerate more criticism than private individual. So defamation laws that stop legitimate criticism of a government or public official. Violate the right to free speech: Blasphemy: protecting abstract concepts: religions belief or other beliefs or the sensibilities of people that behave them is not ground for restricting freedom of speech. Media and journal: journalist and bloggers face particular risks because of the work they do. Countries therefore have responsibilities to protect their right to freedom of speech restriction on newspapers, substations; etc can affect every ones right to freedom of expression. Whistleblowers: government should never bring criminal 
proceedings against anyone who reveals information about human right abuses. Right and responsibilities freedom speech is one of our most important rights and one of the most misunderstood. Use your freedom of speech to speak out for those that are denied their but use it responsibly. It is a powerful thing. Nigerian's constitution protects the right to freedom of expression and provides that any restriction to this right must be justifiable in a democratic society. The authorities should not exploit concerns about have speech or fake news as a pretext for repression of free speech (FRNC, 1999). In view of this therefore, Radio Jigawa AM Station and Freedom Radio Jigawa FM Station came up with different political radio programmes as "Kowane Gauta Radio Political Programme" "Baki Kan Yanka Wuya Radio Political Programme" and "Kowa Ya Dakko Da Zafi Radio Political Programme" respectively with the view of enlighten people on political awareness (JBC, 2020).It is based on this background that this study seeks to assess the impact of the Radio Political Programmes on Public Political Awareness in Jigawa State, Nigeria

\section{OBJECTIVES OF THE STUDY}

The general objective of the study is to assess the impact of the Radio Political Programmes on Public Political Awareness in Jigawa State, Nigeria, the study sets out to achieve the specific objectives as follows, to:

1. Evaluate political awareness gained by the listeners of the Radio Political Programmes in Jigawa State, Nigeria

2. Ascertain the level of audience motivation for listening to the Radio Political Programmes in Jigawa State, Nigeria

3. Determine the level of influence of Radio Political Programmes on audience Political decisions in Jigawa State, Nigeria

\section{METHODOLOGY}

The study area is Jigawa State one of thirty-six states that constitute Federal Republic of Nigeria. The state has 27 local governments council, covers an area of 8,940 square kilometers, situated in the northwestern part of the country between latitudes $11.00^{\circ} \mathrm{N}$ to $13.00^{\circ} \mathrm{N}$ and longitudes $8.00^{\circ} \mathrm{E}$ to $10.15^{\circ} \mathrm{E}$, has 3 senatorial districts, 288 political wards. The state also has five emirates namely Dutse, Gumel, Hadejia, Kazaure and Ringim. Kano State and Katsina State border Jigawa to the west, Bauchi State to the east and Yobe State to the northeast. To the north, Jigawa shares an international border with Zinder Region in The Republic of Niger, which is a unique opportunity for cross-border trading activities. The government readily took advantage of this by initiating and establishing a free trade zone at the border town of Maigatari in Niger. The state has a total land area of approximately 22,410 square kilometers. Its topography is characterized by undulating land, with sand dunes of various sizes spanning several kilometres in parts of the State. The southern part of Jigawa comprises the basement complex while the northeast is made up of sedimentary rocks of the Chad Formation. The main rivers are Hadejia, Kafin Hausa and Iggi Rivers with a number of tributaries feeding extensive marshlands in north-eastern part of the State. Hadejia - Kafin Hausa River traverses the state from west to east through the Hadejia-Nguru wetlands and empties into the Lake Chad Basin (JARDA, 2020). It has a population of 5,368,612, projected from 2006 census (NPC, 2006). The population of the study includes the population of Jigawa state numbered 5,368,612, the sample size of the study were determined using Research advisor (2006) sample size table. Therefore, 384 were used as a sample size of the study. Simple Random Cluster Sampling was used for this study. Sample sizes of the study 
were drowned from the eight (8) LGAs of Jigawa, 48 respondents from each of the following 7 LGA: Gwaram, Jahun, Megatari, Buji, Garki, Ringim, Kyawa and Birnin Kudu were used; Primary data were mainly obtained using structural questionnaires supplemented by verbal interviews. The collected data for the study were analyzed using descriptive statistics i.e. frequency distribution and percentages were use to analyze data. The research is significant it could serve as a document and a guide to policy makers' formulation radio political programmes; findings serve as a guide for programmes whose aim is to increase public awareness on political arena. In addition to that, the research could provide some vital information in Jigawa State radio political programmes. The research if published will be significant to provide a way out for political problems. The "Kowane Gauta" "Baki Kan Yanka Wuya" and "Kowa Ya Dakko Da Zafi" Radio Political Programmes are seen as a multi faceted communication that uses (multimedia approaches) Freedom Radio Dutse FM station and Radio Jigawa AM as an agent of political awareness in the study area, but this study focus on the impact of the Radio Political Programmes on Public Political Awareness in Jigawa State, Nigeria

\section{RESULT AND DATA PRESANTATION}

Table 1: Evaluate political awareness gained by the listeners of the Radio Political Programmes in Jigawa State, Nigeria

\begin{tabular}{|c|c|c|c|c|c|}
\hline \multirow{3}{*}{$\mathbf{S} / \mathbf{N}$} & \multirow{3}{*}{ ITEMS } & \multicolumn{4}{|c|}{ RESPONSES } \\
\hline & & \multicolumn{2}{|c|}{ AGREED } & \multirow{2}{*}{\multicolumn{2}{|c|}{$\begin{array}{c}\text { NOT } \\
\text { AGREED }\end{array}$}} \\
\hline & & & & & \\
\hline & & Freq. & Per. \% & Freq. & Per. \% \\
\hline 1. & $\begin{array}{l}\text { I acquire to know about the programmes through my } \\
\text { friends }\end{array}$ & 256 & $66.7 \%$ & 128 & $33.3 \%$ \\
\hline 2. & $\begin{array}{l}\text { I obtain to know about the programmes through my } \\
\text { family }\end{array}$ & 249 & $64.8 \%$ & 135 & $35.2 \%$ \\
\hline 3. & I listen to the programmes at home & 253 & $65.9 \%$ & 131 & $34.1 \%$ \\
\hline 4. & I listen to the programmes alone & 207 & $53.9 \%$ & 177 & $46.1 \%$ \\
\hline 5. & I listen to the programmes with families & 195 & $50.8 \%$ & 189 & $49.2 \%$ \\
\hline \multirow{2}{*}{$\begin{array}{ll}6 . \\
7\end{array}$} & I listen to the programmes with friends & 261 & $68.0 \%$ & 123 & $32.0 \%$ \\
\hline & I listen the political programmes for one year & 287 & $74.7 \%$ & 97 & $25.3 \%$ \\
\hline$\frac{7 .}{8 .}$ & I listen to the political programmes for two years & 345 & $89.8 \%$ & 39 & $10.2 \%$ \\
\hline 9. & I listen to the political programmes for 3 year & 356 & $92.7 \%$ & 28 & $7.3 \%$ \\
\hline 10. & $\begin{array}{l}\text { I discuss the issues raised in the programmes with } \\
\text { my family }\end{array}$ & 239 & $62.2 \%$ & 145 & $37.8 \%$ \\
\hline 11. & $\begin{array}{l}\text { I discuss the issues raised in the programmes with } \\
\text { my friends }\end{array}$ & 249 & $64.8 \%$ & 135 & $35.2 \%$ \\
\hline 12. & $\begin{array}{l}\text { I discuss the issues raised in the programmes with } \\
\text { my fellow workers }\end{array}$ & 304 & $79.2 \%$ & 80 & $20.5 \%$ \\
\hline \multicolumn{2}{|r|}{ TOTAL } & 3202 & $69.5 \%$ & 1406 & 30.5\% \\
\hline
\end{tabular}


Journal DOI: www.doi.org/10.46654/ij.24889849

Article DOI: www.doi.org/10.46654/ij.24889849.e7217

Table 2: Ascertain the level of audience motivation for listening to the radio political programmes in Jigawa State, Nigeria

\begin{tabular}{|c|c|c|c|c|c|}
\hline \multirow[b]{3}{*}{ S/N } & \multirow[b]{3}{*}{ ITEMS } & \multicolumn{4}{|c|}{ RESPONSES } \\
\hline & & \multicolumn{2}{|c|}{ AGREED } & \multicolumn{2}{|c|}{$\begin{array}{c}\text { NOT } \\
\text { AGREED }\end{array}$} \\
\hline & & Freq. & Per. \% & Freq. & Per. \% \\
\hline 1. & The radio political programmes motivate listeners & 305 & $79.4 \%$ & 79 & $20.6 \%$ \\
\hline 2. & Broadcasting time is convenient to the listeners & 196 & $51.1 \%$ & 184 & $47.9 \%$ \\
\hline 3. & $\begin{array}{l}\text { Wasikaar malam Dila and Wasikar Malam } \\
\text { Botorami motivate listeners }\end{array}$ & 254 & $66.1 \%$ & 130 & $33.9 \%$ \\
\hline 4. & $\begin{array}{l}\text { Presentation of Radio Political Programmes in } \\
\text { Hausa language are convenient }\end{array}$ & 194 & $50.5 \%$ & 190 & $49.5 \%$ \\
\hline 5. & Insight of information providing motivate listeners & 301 & $78.4 \%$ & 83 & $21.6 \%$ \\
\hline 6. & Issues raising in the programmes motivate listeners & 315 & $82.0 \%$ & 69 & $18.0 \%$ \\
\hline & TOTAL & 1565 & $68.0 \%$ & 739 & 32.0\% \\
\hline
\end{tabular}

Table 3: Determine the level of influence of Radio Political Enlightenment Programmes on audience Political decisions in Jigawa State, Nigeria

\begin{tabular}{|c|c|c|c|c|c|}
\hline \multirow[b]{3}{*}{$\mathbf{S} / \mathbf{N}$} & \multirow{3}{*}{ ITEMS } & \multicolumn{4}{|c|}{ RESPONSES } \\
\hline & & \multicolumn{2}{|c|}{ AGREED } & \multicolumn{2}{|c|}{ NOT AGREED } \\
\hline & & Freq. & Per. \% & Freq. & Per. \% \\
\hline 1. & $\begin{array}{l}\text { The programmes provide avenue for political } \\
\text { discussion }\end{array}$ & 373 & $97.1 \%$ & 11 & $2.9 \%$ \\
\hline 2. & The programmes provide awareness to the people & 369 & $96.1 \%$ & 15 & $3.9 \%$ \\
\hline 3. & I recognize the political programmes as educative & 331 & $86.2 \%$ & 53 & $13.8 \%$ \\
\hline 4. & $\begin{array}{l}\text { The programmes change my perception about } \\
\text { political thought }\end{array}$ & 368 & $95.8 \%$ & 16 & $4.2 \%$ \\
\hline 5. & $\begin{array}{l}\text { The political programmes influence my political } \\
\text { decisions }\end{array}$ & 299 & $77.9 \%$ & 85 & $22.1 \%$ \\
\hline 6. & $\begin{array}{l}\text { The programmes create effective political } \\
\text { interaction }\end{array}$ & 379 & $98.7 \%$ & 5 & $1.3 \%$ \\
\hline 7. & $\begin{array}{l}\text { The programme encourage listeners to participate } \\
\text { in political arena }\end{array}$ & 198 & $51.6 \%$ & 186 & $48.4 \%$ \\
\hline 8. & $\begin{array}{l}\text { The political programmes influence my political } \\
\text { decision }\end{array}$ & 288 & $75 \%$ & 96 & $25 \%$ \\
\hline 9. & $\begin{array}{l}\text { The programmes enable me to have trust and } \\
\text { confidence with politicians }\end{array}$ & 147 & $28.3 \%$ & 237 & $61.7 \%$ \\
\hline 10. & $\begin{array}{l}\text { The programme influence me to change my } \\
\text { political affiliation }\end{array}$ & 298 & $77.6 \%$ & 86 & $22.4 \%$ \\
\hline 11. & The programme make me engage on political rally & 170 & $44.3 \%$ & 214 & $55.7 \%$ \\
\hline 12. & $\begin{array}{l}\text { I learnt how to lay our complaint against } \\
\text { politicians }\end{array}$ & 202 & $52.6 \%$ & 182 & $47.4 \%$ \\
\hline 13. & The programmes help in solving our problems & 199 & $51.8 \%$ & 185 & $48.2 \%$ \\
\hline & TOTAL & 3821 & $73 \%$ & 1371 & $27 \%$ \\
\hline
\end{tabular}




\section{FINDINGS AND DISCUSSIONS}

In summary, the research made some major findings as follows:

Table 1: Political awareness gained by the listeners of the Radio Political Programmes in Jigawa State, Nigeria, 66.7\% listeners were found that they acquire to know about the programmes through their friends, $64.8 \%$ pointed that they know about the programmes through their family, $65.9 \%$ of the respondents listen to the programmes at their homes, 53.9 admitted were listen to the programmes alone, $68.0 \%$ greed they listen to the programmes with friends, $74.7 \%$ said that they have been listen to the political programmes for one year, $89.8 \%$ have been listen the programmes for two years, $92.7 \%$ have been listening the programmes for 3 years, $62.2 \%$ discuss the issues raised in the programmes with their family, $64.8 \%$ pointed out that they discuss the issues raised in the programmes with their friends, $79.2 \%$ discuss the issues raised in the programmes with their fellow workers.

Table 2: The level of audience motivation for listening to the radio political programmes in Jigawa State, Nigeria, $79.4 \%$ agreed radio political programmes motivate listeners, $51.1 \%$ Broadcasting time is convenient to the listeners, 66.1\% Wasikar Mallam Dila da Wasikar Malam Botorami motivate listeners, $50.5 \%$ presentation of Radio Political Programme in Hausa language are convenient, $78.4 \%$ insight of information providing in the programme motivate listeners, $82.0 \%$ Issues raising in the programmes motivate listeners.

Table 3: The level of influence of Radio Political Enlightenment Programmes on audience Political decisions in Jigawa State, Nigeria, 97.1\% the programmes provide avenue for political discussion, $96.1 \%$ the programmes provide awareness to the people, $86.2 \%$ I recognize the political programmes as educative, $95.8 \%$ the programmes change my perception about political thought, $77.9 \%$ The programmes change my perception about political thought, $98.7 \%$ the programmes create effective political interaction, $51.6 \%$ the programmes encourage listeners to participate in political arena, $75 \%$ the political programmes influence my political decision, $28.3 \%$ the programmes enable me to have trust and confidence with politicians, $77.6 \%$ the programme influence me to change my political affiliation, $44.3 \%$ the programme make me engage on political rally, 52.6\% I learnt how to lay my complaint against politicians, $51.8 \%$ the programmes help in solving our problems.

\section{CONCLUSION AND RECOMMENDATION}

The result revealed that: the Radio Political Programmes on Public Political Awareness in Jigawa State, Nigeria was significantly effective with 69.5\% Majority of the listeners of the Radio Political Programmes agreed that gained Political Awareness through listening the Radio Political Programmes in Jigawa State, Nigeria, $68.0 \%$ of audience of the programmes motivated through listening to the Radio Political Programmes in Jigawa State, Nigeria, 73\% Radio political Programmes facilitate their decision politically, Nigeria. Therefore, Radio Political Programmes on Public Political Awareness in Jigawa State, Nigeria were found very effective because $70 \%$ of the respondents positively agreed that radio political programme strongly effective, in line with yahaya (2003), Sanjay (2013), Kupuniyi (2000), Bay (2007), Folarin (1990), Ozturk (2003), Mcquil (1998), Mendelson (1966), Mihalis (2006), Kakade (2013) and Okigbo (1990). The following recommendations were made (i) Freedom Radio Dutse should improve transmission in Kazaure, Gumel and Hadejia emirates (ii) Radio anchors should upgrade balance of information (iii) improve radio teaching and learning process (iv) community should involve in sponsoring radio programmes. 


\section{REFERENCES}

Amnesty International (2020). Amnesty International UK Last updated 12 June 2020 Amnesty International UK 18 may 2020. Retrieved on $1^{\text {st }}$ December, 2020

Bay, N. (2007). Radyo ve Televizyon Yayıncılığı, İstanbul: NKM Yayınları.

Dare O. (1990). The role of the Nigeria mass media in national rural development and transformation. Media Forum Organized, IITA, Ibadan 3-11.

Ekumankama O.O. (2000). Farmers' level of satisfaction with formal agricultural information source in Umuahia, Abia state, Nigeria. Journal of Sustainable Agriculture and Environment. Michael Okpara, Uni Agric Umudike. 2(2): 257-263.

Folarin B. (1990). Boadcasting for Rural Development in Nigeria. Abeokuta: Millennium Investments Limited

FRNC (1999). Federal Republic of Nigerian Constitution, Section 39(1) of the 1999 Constitution of Nigeria

HRA, (2020). Human Rights Act: Article 10 Freedom of expression Equality and www.equality.humanriht.com Retrieved on 12 June, 2020

JARDA (2020)

Jigawa Broadcasting Corporation (2020). Broadcasting House, Sani Abacha way, Dutse Local Government, Jigawa State, Nigeria.

Kakade O. (2013). Credibility of Radio Programmes in the Dissemination of Agricultural Information: A Case Study of Air Dharwad, Karnataka state, India IOSR Journal of Humanities and Social Science (IOSR-JHSS) Volume 12, Issue 3 18-22 e-ISSN: 22790837, p-ISSN: 2279-0845. www.Iosrjournals.Org

Kuponiyi, F.A. (2000). Mass Media in Agricultural Development: The use of Radio by Farmers of Akinyele Local Government Area of Oyo State, Nigeria, Nigerian Agricultural Development Studies. Volume. 14, No 1,

Mcleish, (1978) Radio production: $3^{\text {rd }}$ edn, Bath press: Great Britain

Mcquil, D. (1980) Towards a sociology of mass communication, Middlesex: collier publication

Mihalis k. (2006). The Functions Of Radio And Their Future In The Evolving Radio Broadcasting International Journal Of Social Science doi number:http://dx.doi.org/10.9761/jasss3328 number: 43 , p. 221-241, spring i 2016 yayın süreci (JASSS)

Moemeka, A.A. Local Radio: community education for development ABU Press Ltd, Zaria.

National Human Right Nigeria (2020). Nigerian Fundamental Human Right, Article 10 Freedom of expression Equality and www.equality.humanriht.comLast Updated 12 June 2020. Retrieved on $1^{\text {st }}$ December, 2020 
National Population Commission (2006). 2006 Population and Housing census of the Federal republic of Nigeria, population and housing table, Kano state, march 2006 (vol. $1 \mathrm{~T}-\mathrm{D}-\mathrm{S}: 1.19$ )

Nwuzor B (2000). Nature and role of agricultural extension in economic development. ECONAS publishing Company, Enugu.

Ojebode, A. (2003) Radio as a development communication medium: types, formats, roles and limitations. In Soola, E.O. (ed) Communicating for development purposes. Ibadan, Krafi Book Ltd Nigeria.

Okwu, O. J. and Dauda, S. (2011). Extension Communication Channels Usage and Preference by Farmers in Benue State Nigeria. Journal Agricultural Extension and Rural Development. Pp. 88-94.

Omenesa Z. E. (1997). Rural agricultural radio in Nigeria. an overview of the national agricultural extension and research Liaison Service (NAERLS) Farm broadcaster. J. Agric Ext. pp. 74-81.

Öztürk, S. (2003). “Gençlerin Radyo Dinleme Alışkanlıkları ve Radyonun İşlevi” İstanbul Üniversitesi İletişim Fakültesi Dergisi, Cilt: 18, Sayı: 1

Research Advisor (2006), Population sampling size determination table Retrieved on October 25, $2020 \mathrm{from} \mathrm{http//researchadvisors.com}$

Sanjay, A. (2013). Broadcasting is key communication medium in emergencies ITU Report to highlight role of terrestrial radio and TV in disseminating critical information htt://youtu.be/6011GXZUddM, eee.itu.int/go/ITU-R/RWP6A-2013

World Health Organization (1978). Declaration of Alma Ata.. Adopted at International Conference on Primary Health Care: Report of the on PHC. Alma Ata. USSR. Geneva; 6-12 September 1978

Yahaya, M.K. (2003) Gender consideration in radio option for development support communication: empirical evidence from Northern Nigeria. In Soola, E.O. (ed) Communicating for development purposes. Ibadan, Krafi Book Ltd Nigeria.

Zaria M. B, Omenesa Z. E. (1992). Radio Script writing and production. Proceedings of the orientation and Refreshers' Courses for the NAERLS staff, February 17-22, ABU, Zaria. 